\title{
Diagnostic Performance of T2- weighted sequences in Upper Abdominal Magnetic Resonance Imaging: BLADE Technique or HASTE Technique?
}

\author{
${ }^{1}$ Department of Radiology, Health Sciences University, \\ Istanbul Umraniye Training and Research Hospital, \\ Istanbul, Turkey \\ ${ }^{2}$ Department of Radiology, Memorial Sloan Kettering \\ Cancer Center, New York, USA \\ ${ }^{3}$ Department of Radiology, Tekirdağ Namik Kemal \\ University, Tekirdag, New York, Turkey
}

Safiye Sanem Dereli Bulut, ${ }^{1}$ Fuad Nurili, ${ }^{2}$ Hadi Sasani, ${ }^{3}$ Omer Aras, ${ }^{2}$ Yasar Bukte ${ }^{1}$

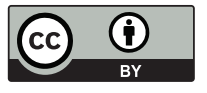

This work is licensed under a Creative Commons Attribution 4.0 International License

Received: 2019-02-09

Accepted: 2019-02-20

UDC: 616.1

\section{J Clin Med Kaz 2019;1(51):37-43}

Corresponding Author: Safiye Sanem Dereli Bulut,

MD, Department of Radiology, Health Sciences

University, Istanbul Umraniye Training and Research

Hospital, Istanbul, 34668, Turkey. Tel.: +905327763354

Email: ssanembulut@gmail.com

\section{Abstract}

Objective: To evaluate T2-weighted BLADE tecnique for evaluating intra-abdominal organs and lesions, especially the gastrointestinal wall and pathologies, and to compare the findings with HASTE.

Material and Methods: Sixty patients (mean age: 47.2 years, range 19-88) (32 males, 28 females) referred to our institution for upper abdominal Magnetic Resonance Imaging (MRI) examinations with various indications between January 2015 and May 2015 were included in our study. All examinations were performed on a 1.5 Tesla MR device and no anti-peristaltic drug was administered. Images were retrospectively and independently evaluated by two radiologists. A qualitative evaluation was performed to assess images regarding the presence of artifacts and diagnostic quality, the anatomical detail of the upper abdominal organs and structures (contour sharpness, contrast of tissue, parenchyma and internal wall structure) and any present pathologies and lesions in the organs (lesion contour sharpness and size, internal structure properties, morphological characteristics). A quantitative evaluation was performed to calculate the contrast-to-muscle ratios (CMR) of the internal organs and lesions. The distribution of the variables was statistically checked by Kolmogorov Smirnov test. Paired-samples t- test was used for quantitative data.

Results: BLADE was significantly associated with reduced artifacts ( $p$ $<0.0001$ ) and increased image quality compared with HASTE. The highest agreement between both observers was that motion artifacts were reduced (Gwet's AC2 = 0.94). In addition, observers agreed that the parenchymal structure of the upper abdominal solid organs and the anatomic details of the stomach wall structure were better with BLADE (Gwet's AC2 $=0.87$ ). In most cases, both observers preferred BLADE $(p<0.0001)$ for evaluating images and lesion morphology.

Conclusion: In upper abdominal MRI examination, artifacts, especially movement artifacts, were significantly reduced by BLADE, yielding more valuable data for the evaluation of the gastrointestinal system wall structure and its pathologies, especially considering the organs near to the diaphragm and retroperitoneal organs as well as vascular structures.

Keywords: Upper abdominal MR imaging tecniques, BLADE/ PROPELLER, HASTE, MR artifacts

\section{ІШТІН ЖОҒАРЫ БӨЛІГІНЕ МАГНИТТІ-РЕЗОНАНСТЫ ТОМОГРАФИЯДА Т2-ӨЛШЕНГЕН БІРІЗІДІЛІКТІН ДИАГНОСТИКАЛЫҚ СИПАТТАМАЛАРЫ: ВLADЕ ТЕХНИКАСЫ НЕМЕСЕ НАSТЕ ТЕХНИКАСЫ МА? Сафи Санем Дерели Булут, ${ }^{1}$ Фуад Нурили, ${ }^{2}$ Хади Сасани, ${ }^{3}$ Омер Арас, ${ }^{2}$ Ясар Букте ${ }^{1}$ \\ 'Радиология бөлімі, Медицина ғылымдарының университеті, Умрание ғылыми-зерттеу және оқыту клиникасы, Ыстамбүл, Түркия \\ ${ }^{2}$ Радиология бөлімі, Слоан-Кеттеринг мемориалдық онкология орталығы, Нью-Йорк, АҚШ \\ ${ }^{3}$ Радиология бөлімі, Намик Кемаль Университеті, Текирдаг, Түркия}


Материалдар мен әдістер: Зерттеуге 60 пациенттер қамтылды (орташа жасы: 47,2 жас, ауқымы 19-дан 88-ге дейін) (32 ерлер, 28 әйелдер), олар 2015 жылдың қаңтар айынан бастап мамыр айы аралығында әртүрлі көрсетімдермен іш қуысының жоғары бөлігін магнитті резонансты тексеру үшін біздің мекемеге жіберілген болатын. Барлық зерттеулер 1,5 Тесла аспабында жүргізілді, керітолқушылық құрал енгізілмеді. Көрінулерді екі рентгенологтар ретроспективті және тәуелсіз бағалады.

Жоғары органдар мен іш қуысы құрылымдарының (контурдың айқындылығы, тін контрасті, ішкі қабырғасының паренхимасы мен құрылымы) жалған өзгерістері мен диагностикалық сапаларының, анатомиялық бөлшектерінің бар болуына қатысты көрінулерді және органдардағы кез-келген патологиялар мен зақымдануларды (зақымдану айқындылығы мен мөлшері, ішкі құрылымның қасиеттері, морфологиялық сипаттамалары) бағалау үшін сапалы бағалау жүргізілді. Сандық бағалау ішкі органдар мен зақымданулардың бұлшық етке (CMR) контраст қатынасын есептеу үшін орындалды. Айнымалы шаманы үйлестіру Колмогоров-Смирнов өлшемдері бойынша статистикалық тексерілді. Сандық деректер үшін жұп үлгілердің t-өлшемдері пайдаланылды.

Нәтижелері: BLADE көп жағдайда жалған өзгерістердің азаюымен және HASTE-пен салыстырғында (p <0,0001) және көріну сапасының артуымен байланысты болды. Екі бақылаушылар арасында ең жоғарғы келісім қозғалыстардың жалған өзгерістері азайғаны болды (АС2 Gwet = 0,94). Бұдан басқа, іш қуысының жоғары органдарының паренхиматозды құрылымы және асқазан қабырғалары құрылымының анатомиялық бөлшектері BLADE (AC2 Gwet = 0,87) пайдаланған кезде жақсырақ болды. Көп жағдайда екі бақылаушы да зақымданудың көрінулерін және морфологияларын бағалау үшін BLADE ( $<<0,0001)$ пайдалануды дұрыс деп есептеді.

Қорытынды: Іш қуысы жоғары бөлімдеріне МРТ-зерттеулер жүргізген кезде жасанды өзгерістер қуысы, әсіресе қозғалыстың жасанды өзгерістері BLADE көмегімен айтарлықтай азайды, бұл асқазан-ішек жолы қабырғаларының құрылымы мен онын паталогияларын бағалау үшін құнды деректерді береді, әсіресе диафрагма мен ішастар органдары қасындағы органдарды, сондай-ақ тамырлы құырлымдарды ескере отырып.

Негізгі сөздер: іш қуысының жоғарғы бөлігі, магнитті-резонансты томографиядағы жалған өзгерістер, Т2-өлшенген бірізділіктің, НАSTE бірізділік BLADE бірізділік

\section{ДИАГНОСТИЧЕСКИЕ ХАРАКТЕРИСТИКИ Т2-ВЗВЕШЕННЫХ ПОСЛЕДОВАТЕЛЬНОСТЕЙ В МАГНИТНО- РЕЗОНАНСНОЙ ТОМОГРАФИИ ВЕРХНЕЙ ЧАСТИ ЖИВОТА: ТЕХНИКА ВLАDЕ ИЛИ ТЕХНИКА НАSTЕ?}

Сафи Санем Дерели Булут ${ }^{1}$, Фуад Нурилиㄹ, Хади Сасани ${ }^{3}$, Омер Арас², Ясар Букте

'Отделение радиологии, Университет медицинских наук, Научно-исследовательская и обучающая клиника Умрание, Стамбул, Турция

${ }^{2}$ Отделение радиологии, Мемориальный онкологический центр Слоана-Кеттеринга, Нью-Йорк, США

${ }^{3}$ Отделение радиологии, Университет Намик Кемаль, Текирдаг, Турция

\section{PЕЗЮME}

Цель: оценить T2-взвешенную методику BLADE для оценки органов брюшной полости и поражений, особенно желудочно-кишечной стенки и патологий, и сравнить результаты с HASTE.

Материалы и методы: В исследование были включены 60 пациентов (средний возраст: 47,2 года, диапазон от 19 до 88) (32 мужчины, 28 женщин), которые были направлены в наше учреждение для обследования магнитного резонанса верхней части живота (МРТ) с различными показаниями в период с января 2015 года по май 2015 года. Все исследования проводились на приборе 1,5 Тесла, и антиперистальтический препарат не вводился. Изображения были ретроспективно и независимо оценены двумя рентгенологами. Была проведена качественная оценка для оценки изображений, касающихся наличия артефактов и диагностического качества, анатомических деталей верхних органов и структур брюшной полости (резкость контура, контраст ткани, паренхима и структура внутренней стенки) и любых имеющихся патологий и поражений в органах (резкость и размер очага поражения, свойства внутренней структуры, морфологические характеристики). Количественная оценка была выполнена для расчета отношения контраста к мышце (CMR) внутренних органов и поражений. Распределение переменных было статистически проверено по критерию Колмогорова Смирнова. Для количественных данных использовался t-критерий парных образцов.

Результаты: BLADE был в значительной степени связан с уменьшением артефактов ( $<<0,0001)$ и повышенным качеством изображения по сравнению с HASTE. Самое высокое согласие между обоими наблюдателями было то, что артефакты движения были уменьшены (AC2 Gwet = 0,94). Кроме того, наблюдатели согласились с тем, что паренхиматозная структура верхних органов брюшной полости и анатомические детали структуры стенки желудка были лучше при использовании BLADE (AC2 Gwet = 0,87). B большинстве случаев оба наблюдателя предпочитали BLADE ( $<<0,0001)$ для оценки изображений и морфологии поражения.

Заключение: При МРТ-исследовании верхних отделов брюшной полости артефакты, особенно артефакты движения, были значительно уменьшены с помощью BLADE, что дает более ценные данные для оценки структуры стенки желудочно-кишечного тракта и ее патологий, особенно с учетом органов вблизи диафрагмы и забрюшинных органов, а также сосудистых структур.

Ключевые слова: верхний отдел брюшной полости, артефакты в магнитно-резонансной томографии, Т2-взвешенная последовательность, последовательность HASTE последовательность BLADE

\section{Introduction}

In routine clinical practice, magnetic resonance imaging (MRI) is highly promising for verifying lesions that are not accurately diagnosed by other radiological methods, especially ultrasonography [1-4]. Nonetheless, in abdominal imaging, a number of factors have hampered its use in routine clinical practice. In particular, T2-weighted imaging with contrast is understood to be an extremely important sequence for diagnostic information but is often be marred by motion artifacts [1,2]. These artifacts occur frequently due to voluntary or involuntary patient movement, respiration, peristalsis, and blood flow, causing organ contours to appear blurry and malignant lesions undetectable on imaging [1-3]. While attempts to reduce artifacts have included anti-peristaltic drugs, fasting, meticulous patient fixation and the use of single-shot pulse sequences, they have yet to produce an optimal solution for clinical practice [1-3].

Turbo spin echo (TSE) imaging methods are increasingly popular for abdominal MRI as they use a shortened scanner time but yield high T2-weighted contrast [1-3]. The shortened scanner time reduces motion artifacts. However, a known issue for TSE is that T2 decay is ongoing during imaging, resulting in signal non-uniformity along the lines of the k-space and concomitant blurring in the images [1-3]. One approach to overcoming this is to use non-Cartesian sampling $[1,5]$. As opposed to standard Cartesian sampling, non-Cartesian sampling confers better motion immunity and compensates for signal non-uniformity [46]. In particular, the Periodically Rotated Overlapping Parallel Lines with Enhanced Reconstruction (PROPELLER) technique has shown to be highly valuable. It compensates for in-plane rotation and in-plane translation as regards motion immunity and yields excellent $\mathrm{T} 2$-weighted contrast when implemented as a TSE sequence [5,7].

BLADE is a variant technique under the proprietorship of Siemens that oversamples the k-space by acquiring multiple echo trains (or in other words, blades) that partially overlap with one another in a radial fashion [5]. Thus far, a number of studies have already demonstrated the superiority of BLADE over standard Cartesian k-space acquisition in the brain, cervical spine and spinal cord, and abdominal region, whereby superiority was demonstrated based mainly on qualitative comparisons [8-11].

The aim of the present study was to compare $\mathrm{T} 2$-weighted BLADE TSE which was recently implemented in our institution 
with HASTE (Half-Fourier-Acquired Single-shot Turbo spin Echo) in the upper abdomen, namely the intra-abdominal organs and lesions, particularly gastrointestinal wall pathologies. HASTE is a rapid T2-weighted sequence that acquires images in less than one second that is promising for overcoming motionrelated artifacts. We performed qualitative and quantitative assessments on overall image quality, contrast, and diagnostic information to determine whether BLADE is superior to HASTE.

\section{Material and methods}

\section{Patients}

The single-institution study was approved by the institutional review board and all patients gave written informed consent. The study protocol complied with the version of the Helsinki Convention that was current at the time the study was designed. We retrospectively identified consecutive patients referred to our department by indication of upper abdominal MR examination for various reasons between January 2015 and May 2015.

\section{MRI Protocol}

MRI was performed with the patient lying in the supine position on a 1.5-T whole body scanner (Magnetom Avanto; Siemens Healthcare, Erlangen, Germany) using a six-channel phased array body coil. The scanning protocol included threeplane (axial, coronal, and sagittal) pulse sequences with steadystate free precession (TrueFisp), T1-weighted two-dimensional gradient echo, diffusion weighted imaging, and T1- and T2weighted TSE sequences. Contrast-enhanced dynamic threedimensional axial T1-weighted FLASH: TR $162 \mathrm{msec}$; TE $4 \mathrm{msec}$; SL $8 \mathrm{~mm}$; FA 30; matrix 154 x256; TA 18 seconds per slice set; Dynamic image sets were collected before and immediately, 30 seconds, and 60 seconds after the bolus administration of paramagnetic contrast at a dose of $0.1 \mathrm{mmol} /$ kg (Gd-DTPA, Magnevist; Schering, Berlin, Germany). The agent was administered with an automated injector at a rate of $2.5 \mathrm{~mL} /$ second (Medrad Spectris, Pittsburgh, PA).

TSE sequences were performed with the HASTE sequence (TR: 1350 ms, TE: 92 ms, FA: 160 degree, Slice thickness: 4 $\mathrm{mm}$ ) and the BLADE sequence (TR: $3994 \mathrm{~ms}$, TE: $83 \mathrm{~ms}$, FA: 146 degree, Slice thickness: $4 \mathrm{~mm}$, navigation triggered), both in the axial plane and with fat saturation. The BLADE specific imaging parameters were: $100 \%$ blade coverage and 20 blades. The rotation angles and number of blades were chosen to fully cover $\mathrm{k}$ - space. Imaging was done without administration of any anti-peristaltic drug.

\section{Imaging Assessment}

Image datasets were transferred to a Picture Archiving and Communication System (PACS) workstation for analysis (Centricity® PACS; GE Healthcare, Milwaukee, WI, USA). Fatsuppressed HASTE and BLADE sequences were independently assessed by two radiologists who were experienced in abdominal radiology (8 and 6 years, respectively ). All parameters were evaluated separately for HASTE and BLADE images. Obtained images were evaluated in two reading sessions.

The first reading session consisted of visual (qualitative) evaluation by both radiologists. First, images were assessed in terms of artifacts and scored as follows: $0=$ Absence, $1=$ Low, 2 = Moderate and $3=$ High. Artifacts were classified as bowel peristaltic and respiratory motion artifact, radial artifact, or aliasing artifact. Second, the contour sharpness of the intraabdominal solid organs was examined and scored as follows: 1 = Low, 2 = Moderate and $3=$ High. Third, the parenchymal detail (tissue contrast, internal structural details of parenchyma and morphological detail) of the solid organs and the wall structure of the gastrointestinal organs were evaluated and scored as follows: 1 = Low, 2 = Moderate and $3=$ High. Lastly, any present pathologies and lesions in the organs were scored as follows regarding lesion contour sharpness and size, internal structure properties and morphological characteristics: $1=$ Low, 2 = Moderate and $3=$ High.

The second reading session was a quantitative evaluation performed by the radiologist with 8 years of experience to determine contrast-to-muscle ratios (CMR) of the internal organs and lesions. For solid organs, a $10 \mathrm{~mm} 2$ region of interest (ROI) was drawn from the same location within the parenchyma of the organs (liver, spleen, pancreas, kidney cortex, adrenal gland) for both BLADE and HASTE sequences. An additional two ROIs measuring $10 \mathrm{~mm} 2$ in diameter were determined from the wall of the gastrointestinal tract and from the intraluminal site. Gross lesions, if present, were measured in the same location for both sequences with the ROI covering approximately two thirds of the solid component of the lesion. The mathematical data obtained were used to measure the CMR (contrast to muscle ratio). The ratio in the CMR measurement was made with the erector spina muscle in the paraspinal region of the same cross section. For example, the liver CMR value is calculated by subtracting the muscle signal from the liver parenchymal signal and dividing this difference by the muscle signal.

Statistical Analysis

Quantitative data was analyzed using the paired s amples t-test. The distribution of variables was checked with the Kolmogorov Smirnov test. The reliability of the interobserver agreement was assessed by Gwet's AC2 test. Inter-observer agreement was defined as: $<0.20$ insignificant; $0.21-0.40$ weak; 0.41-0.60 medium; 0.61-0.80 good; $0.81-1.00$ very well. $\mathrm{P}$-values $<0.05$ were considered significant.

Statistical analysis was performed using the Statistical Package for the Social Sciences (SPSS) (version 22.0; SPSS Inc., Chicago, IL, USA).

\section{Results}

A total of 60 patients (mean age 47.2 years; range 19-88) were included in our study: 32 were female and 28 were male.

Qualitative Assessment

When the BLADE sequence was used for evaluation of the presence of artifacts in the first study, the artifacts were significantly reduced compared with the HASTE sequence ( $p$ $<0.0001)$. There was a high degree of agreement between the two observers (Gwet's AC2 = 0.94) (Figure 1).
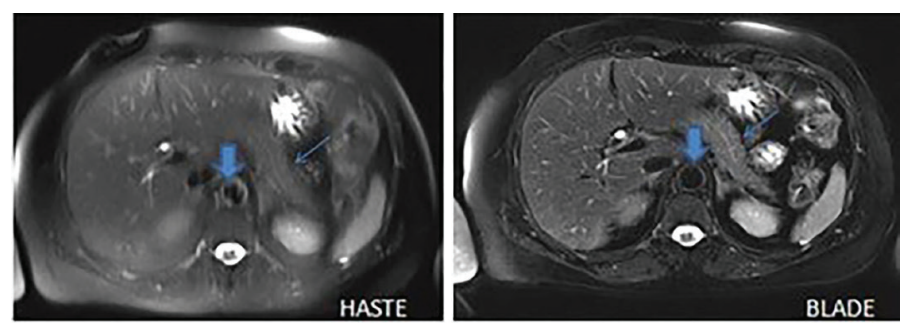

Figure 1 - It is important to note the blurred contours of the liver, spleen and pancreas due to motion artifact in the HASTE sequence compared with the BLADE sequence. In the BLADE sequence, organ contours seen more clearly and were more definite. In the BLADE sequence, inner abdominal and subcutaneous fatty tissue suppressed more homogeneously. This also contributes to the increase in image quality. In addition, the abdominal aortic signal void can be clearly visualized in BLADE sequence (thick arrow). 

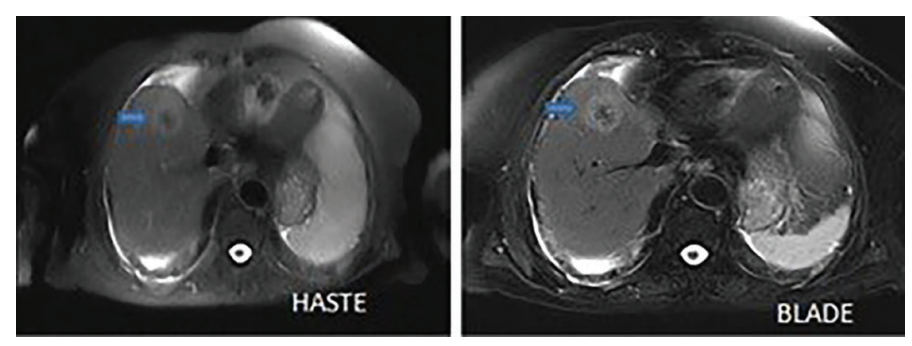

Figure 2a - The contour of the hepatocellular carcinoma compliant lesion located on the anterior segment of the right liver is more clearly visualized with the BLADE sequence compared with the HASTE (thick arrow). In addition, the fat content of the internal structure of the lesion is also seen more clearly in the BLADE sequence.
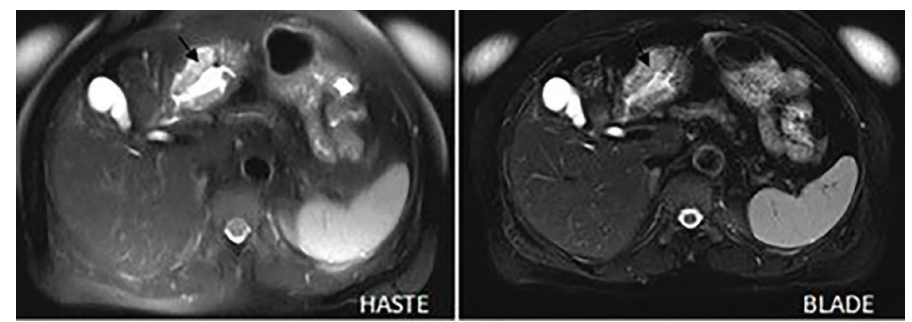

Figure 3 - It is noteworthy that liver and spleen contour sharpness and parenchyma details are more superior with the BLADE sequence when both HASTE and BLADE are acquired with fat suppression on the same plane. In addition, stomach antrum anterior wall thickening and the mass located intramurally to the stomach wall are more clearly seen in BLADE sequence (black arrow).

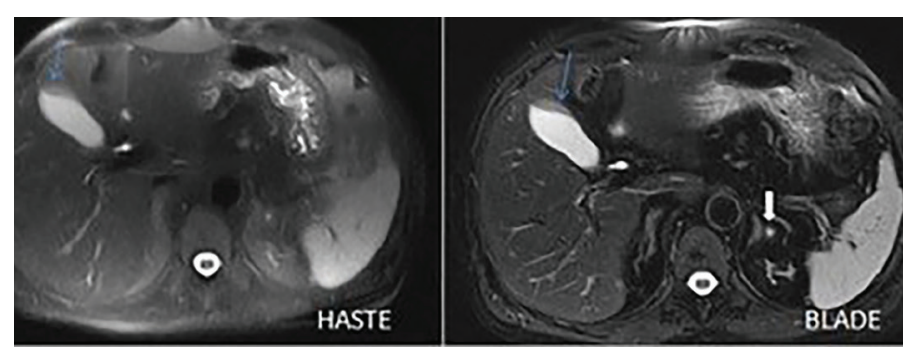

Figure 4a - Retroperitoneal fatty tissue was suppressed homogeneously in BLADE SEQUENCE. There are no artifactrelated distortions in the BLADE sequence when contour blurring in the retroperitoneal structures is present in the HASTE sequence due to diaphragmatic motion. The millimetric cystic lesion (white arrow) present in the lateral margin of the left adrenal gland is easily seen in the BLADE sequence, but is hardly selected in the HASTE sequence. Additionally in HASTE sequence, the heterogenous area in the anterior wall of the bile duct can be considered as an artifact, is also present in the HASTE sequence; therefore a real lesion (thin blue arrow).
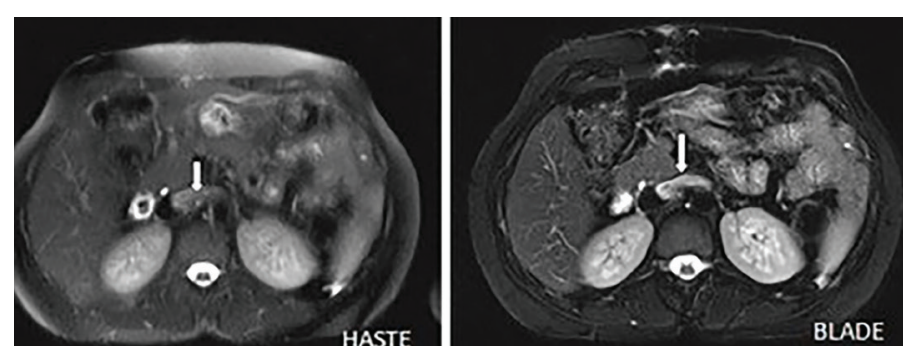

Figure 5a - The thrombus which is extending from left renal vein to inferior vena cava and its internal structure can be evaluated in more detail with BLADE sequence (white arrow).
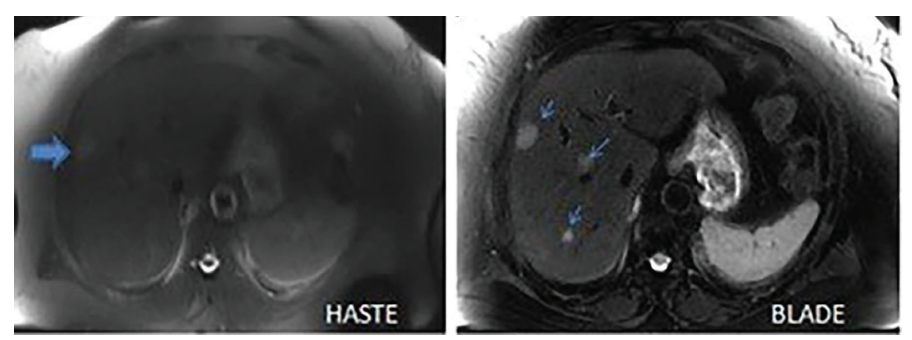

Figure 2b - With the BLADE sequence, 3 parenchymal metastatic lesions (thin arrows) are seen in the liver parenchyma. Only one (thick arrow) can be seen with the HASTE sequence. On second look, one of the other two lesions is faintly distinguishable on the HASTE sequence.

When the contour sharpness of the internal organs was evaluated in terms of the parenchymal structure of solid organs, both observers agreed that the BLADE sequence was superior to the HASTE sequence (Gwet's AC2 $=0.85$ ). In particular, the calcifications present in the solid organ parenchyma were clearly visible in the BLADE sequence (Figure 2).

Gastrointestinal organ wall structure particularly the small intestine and colon was not significantly different in both sequences $(p>0.05)$. However, in regards to the stomach wall structure, both observers concluded that a more detailed morphological evaluation was made with the BLADE sequence (Gwet's AC2 = 0.78) (Figure 3).

Renal cyst was the most common lesion in our study group. The structure of the cysts of a patient with polycystic kidney

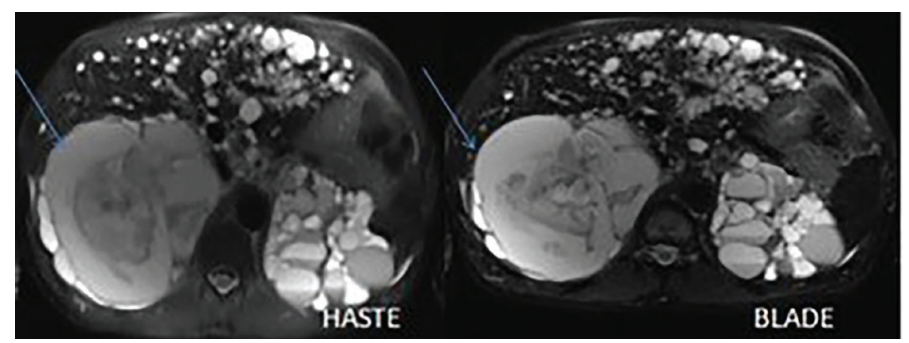

Figure 4b - Numerous omental and mesenteric cysts are seen in the abdomen of policystic kidney disease patient. Additionally, in both kidneys, the large one in the right kidney, there are multiple complex cysts are observed. Some of those cysts have low level signal intensity primarily due to hemorrhage and some are septated. Particularly fibrin-dependent membranes in the right kidney are more clearly evaluated in BLADE sequence.
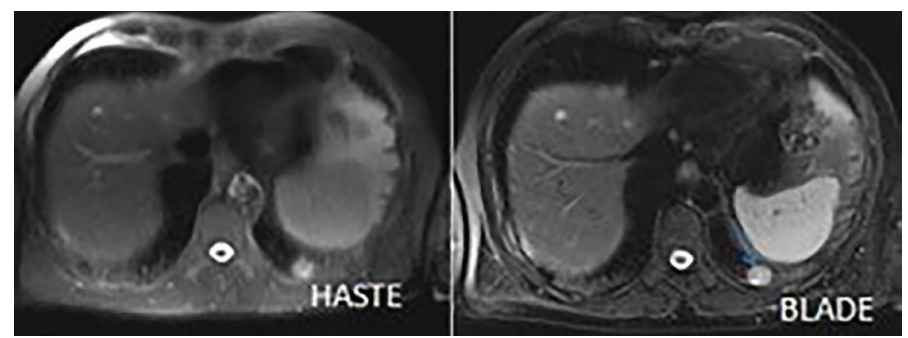

Figure 5b - BLADE sequence reveals the internal structure of nodule, its morphological features and its contours sharply which is located posterobasal, subpleuratic space of inferior left lung in the sub-thoracic sections (thin blue arrow). 
disease was assessed more clearly in the BLADE sequence than in the HASTE sequence. Both observers agreed that the BLADE sequence was superior to the HASTE sequence in terms of evaluating the internal structure of the lesions, especially when looking at the lesions present in the solid organ parenchyma (metastatic liver lesions, hepatocellular cancer or adrenal masses) (Gwet's AC2 $=0.77$ for BLADE vs. Gwet's AC2 $=0.45$ for HASTE) (Figures 4a and 4b).

Vascular structure signal void evaluation was performed more correctly with the BLADE sequence, and a left renal venous thrombus present in a patient was clearly visualized with the BLADE sequence (Figure 5).

When pulmonary parenchymal pathologies entering the image area in the lower thoracic sections were evaluated, the BLADE sequence was found to be superior to HASTE sequence by both observers (Gwet's AC2 $=0.87$ for BLADE vs. Gwet's $\mathrm{AC} 2=0.80$ for HASTE). Interobserver agreement was evaluated as very well.

The inter-observer agreement in the study is summarized in Table 1.

Table 1 Comparision of parameters for T2-weighted BLADE and HASTE Sequences.

\begin{tabular}{|l|l|l|}
\hline & BLADE & HASTE \\
\hline TE $(\mathrm{ms})$ & 83 & 101 \\
\hline TR $(\mathrm{ms})$ & 3994 & 1000 \\
\hline FA (degree) & 146 & 160 \\
\hline FOV (cm) & 350 & 350 \\
\hline Slice thickness (mm) & 4 & 4 \\
\hline Matrix & $320 \times 320$ & $320 \times 320$ \\
\hline Average acquisition time (min:s) & $3: 05 \mathrm{~s}$ & $49 \mathrm{~s}$ \\
\hline
\end{tabular}

TE: Echo Time ; TR: Time of repetition; FA: Flip Angle

Table 2 Quantative analysis of sequences. The reliability of the interobserver agreement was assessed by Gwet's AC2 test. Inter-observer agreement was defined as: $<0.20$ insignificant; 0.21-0.40 weak; 0.41-0.60 medium; 0.61-0.80 good; 0.81-1.00 very well. P-values $<0.05$ were considered significant.

\begin{tabular}{|l|c|c|c|c|}
\hline \multirow{2}{*}{} & \multicolumn{3}{|c|}{ BLADE } & \multicolumn{2}{c|}{ HASTE } \\
\cline { 2 - 5 } & \multicolumn{3}{|c|}{ Sompliance coefficient between observers } \\
\cline { 2 - 5 } & Gwet's AC2 & Standart error & Gwet's AC2 & 0,11051 \\
\hline Contour sharpness & 0,85578 & 0,08877 & 0,62287 & 0,06633 \\
\hline $\begin{array}{l}\text { Internal property of } \\
\text { structures }\end{array}$ & 0,45318 & 0,16299 & 0,77002 & 0,08877 \\
\hline Morphologic detail & 0,87066 & 0,08776 & 0,80734 & 0,11387 \\
\hline Contrast of tissue & 0,78463 & 0,09785 & 0,56354 & 0,12543 \\
\hline Size difference & 0,63524 & 0,12543 & 0,68639 & 0,09085 \\
\hline Artifacts & 0,94955 & 0,04145 & 0,74809 & \\
\hline
\end{tabular}

The table shows the complience coefficient with standart error values. According to the data in the table, the subject where both observers are most compatible is that the T2-weighted BLADE sequence reduces artifacts. And according to observers; the morphological details of lesions or parenchyma of abdominal organs and the counter sharpness of them are more detailed in T2-weighted BLADE sequence than HASTE sequence, too.

\section{Quantitative Assessment}

From the second reading session, the CMR ratio was significantly different for the HASTE and BLADE sequences in terms of the intraabdominal solid organ parenchyma and stomach wall structure and was found to be higher in the BLADE sequence $(\mathrm{p}<0.05)$.

When CMR ratio was evaluated in terms of wall structure for small intestine and colon, no significant difference was found between the HASTE and BLADE sequences ( $p>0.05)$.

\section{Discussion}

In our retrospectively planned upper abdominal study, images obtained with the T2-weighted BLADE sequence showed a significant reduction in artifacts and higher image quality than images obtained with the T2-weighted HASTE sequence, especially in areas near diaphragmatic and gastrointestinal organs where movement is usually markedly elevated.
In the BLADE sequence, ghosting artifact caused by vascular pulsation and respiration and motion artifact caused by patient movement or intestinal peristalsis were noticeably reduced $[9,10]$. The presence of streak artifacts, especially in the periphery, was noteworthy in the abdominal wall. However, when clinical indications of our patients were considered, there was no diagnostic deficiency due to streak artifact $[12,13]$. Similarly, other studies in literature have reported that artifacts observed in the periphery of the field of view did not affect diagnosis and the central location of the studied region remained unaffected $[12,13]$. In addition, in our study, BLADE and HASTE sequences were performed using fat suppression, so the streak artifacts, which were expected to occur in the subcutaneous tissue, were partially overcome.

It has been emphasized in abdominal and pelvic imaging studies that antiperistaltic medication given to the patient will contribute to improved diagnosis with BLADE technique in a 
synergistic manner [14-16]. We did not use any antiperistaltic agents in our study; however, the gastrointestinal system wall structure, especially the stomach, could be clearly demonstrated by the BLADE sequence.

In addition, we noted that when BLADE sequence was used, intraabdominal fat suppression was more homogeneous and the intestinal wall and surrounding tissue pathologies (edema, lymph node) could be evaluated more easily than with the HASTE sequence. However, our study did not involve a detailed statistical comparison for this topic. Perhaps additional work on this topic may be planned in the future.

In our comparative study, CMR was increased when using BLADE. The increased CMR in BLADE images occurred despite the more frequent sampling of the k-space center (1618). This is likely because the bandwidth in BLADE was twice as large as in conventional TSE $(260 \mathrm{~Hz}$ per pixel in BLADE compared with $130 \mathrm{~Hz}$ per pixel in conventional TSE) [4,5]. Another difference between the sequences was the lower angle used in BLADE $\left(146^{\circ}\right)$ compared with HASTE $\left(160^{\circ}\right)$ for the radiofrequency refocusing pulses in the TSE echo train; this may have resulted in increased signal and T2-weighting in the BLADE images [4,5].

While BLADE and HASTE sequences seem to be helpful in compensating for minor motion artifacts (including swallowing, flow phenomena and cerebrospinal fluid pulsation), gross motion was not compensated for sufficiently in all cases. For this purpose, a dedicated motion correction algorithm, which can be performed based on the repetitive acquisition of the central k-space area, might be helpful $[4,10,11]$. BLADE and HASTE sequences were also not sufficient for detecting milimetric cystic lesions (e.g., biliary cysts) $[17,18]$. In the current study, cystic lesions were detected as well-defined contoured and better recognized with internal septation and signal intensity with HASTE.

The HASTE sequence could be used to clarify the milimetric cysts of liver and minor dilatations of the pancreatic ductus more clearly compared with BLADE. This could be due to the slightly longer echo-time of HASTE ( $83 \mathrm{~ms}$ for BLADE vs $101 \mathrm{~ms}$ for HASTE) contributing to differences in fluid visibility or contrast $[17,18]$.

Both sequences were not successful in defining fluid properties. In a study by Froehlich et al using sagittal T2weighted BLADE TSE (without fat-suppression), the authors stated that BLADE may lead to reduce visibility of fluid collections, ascites, or other non-solid structures, producing a handicap for visualizing cystic structures $[17,18]$.

In our study, we found that the BLADE sequence is preferable to HASTE sequence in abdominal MRI examinations, especially in the evaluation of intestinal structures and /or retroperitoneal structures, owing to its higher contrast resolution and better anatomic detail, and there is no need for the use of anti-peristaltic agents.

\section{Acknowledgement}

The authors declared no potential conflicts of interest with respect to the research, authorship, and/or publication of this article.

The authors received no financial support for the research, authorship, and/or publication of this article.

All radiologic images were obtained at Umraniye Training and Research Hospital

Disclosures: There is no conflict of interest for all authors.

\section{References}

1. Bayramoglu S, Kilickesmez Ö, Cimilli T, Kayhan A, Yirik G, Islim F, et al. T2-weighted MRI of the Upper Abdomen:. Comparison of Four Fat-Suppressed T2-weighted Sequences Including PROPELLER (BLADE) Technique. Acad Radiol. 2010; 17(3):368-74. https:// doi.org/10.1016/j.acra.2009.10.015

2. Bellon EM, Haacke EM, Coleman PE, Steiger DA, Gangarosa E. MR Artifacts : Clin Sci. 1986.

3. Finkenzeller T, Menzel C, Fellner F, Fellner C, Stroszczynski C, Schuierer G, et al. \{BLADE\} Sequences in Sagittal T2-Weighted $\{M R\}$ Imaging of the Cervical Spine and Spinal Cord Lesion Detection and Clinical Value. \{RöFo\} - Fortschritte auf dem Gebiet der Röntgenstrahlen und der Bildgeb Verfahren [Internet]. 2013; 186(01):47-53. https://doi.org/10.1055\%2Fs-0033-1350346

4. Forbes KPN, Pipe JG, Bird CR, Heiserman JE. PROPELLER MRI: Clinical testing of a novel technique for quantification and compensation of head motion. J Magn Reson Imaging. 2001; 14(3):215-22. https://doi.org/10.1002/jmri.1176

5. Fujimoto K, Koyama T, Tamai K, Morisawa N, Okada T, Togashi K. BLADE acquisition method improves T2-weighted MR images of the female pelvis compared with a standard fast spin-echo sequence. Eur J Radiol [Internet]. 2011; 80(3):796-801. http://dx.doi. org/10.1016/j.ejrad.2010.08.002

6. Froehlich JM, Metens T, Chilla B, Hauser N, Klarhoefer M, Kubik-Huch RA. Should less motion sensitive T2-weighted BLADE TSE replace Cartesian TSE for female pelvic MRI? Insights Imaging. 2012; 3(6):611-8. https://doi.org/10.1007/s13244-012-0193-9

7. Haneder S, Dinter D, Gutfleisch A, Schoenberg SO, Michaely HJ. Image quality of T2w-TSE of the abdomen and pelvis with Cartesian or BLADE-type k-space sampling: A retrospective interindividual comparison study. Eur J Radiol. 2011; 79(2):177-82. https://oi. org/10.1016/j.ejrad.2009.12.028

8. Hirokawa Y, Isoda H, Maetani YS, Arizono S, Shimada K, Togashi K. MRI artifact reduction and quality improvement in the upper abdomen with PROPELLER and Prospective Acquisition Correction (PACE) technique. Am J Roentgenol. 2008; 191(4):1154-8. https://doi.org/10.2214/AJR.07.3657

9. Lane BF, Vandermeer FQ, Oz RC, Irwin EW, McMillan AB, Wong-You-Cheong JJ. Comparison of sagittal T2-weighted BLADE and fast spin-echo MRI of the female pelvis for motion artifact and lesion detection. Am J Roentgenol. 2011; 197(2):307-13. https://doi. org/10.2214/AJR.10.5918

10. Lewis CE, Prato FS, Drost DJ, Nicholson RL. Comparison of respiratory triggering and gating techniques for the removal of respiratory artifacts in MR imaging. Radiology [Internet]. 1986; 160(3):803-10. https://doi.org/10.1148/radiology.160.3.3737921

11. Michaely HJ, Kramer H, Weckbach S, Dietrich O, Reiser MF, Schoenberg SO. Renal T2-weighted turbo-spin-echo imaging with BLADE at 3.0 Tesla: Initial experience. J Magn Reson Imaging. 2008; 27(1):148-53. https://doi.org/10.1002/jmri.21240

12. Mirowitz SA. Diagnostic pitfalls and artifacts in abdominal MR imaging: a review. Radiology. 1998; 208(3):577-89. https://doi. org/10.1148/radiology.208.3.9722832 
13. Ojeda-Fournier H, Choe KA, Mahoney MC. Recognizing and interpreting artifacts and pitfalls in MR imaging of the breast. Radiographics [Internet]. 2007;27(1):147-164. https://doi.org/10.1148/rg.27si075516

14. Pipe J. Periodically Rotated Overlapping ParallEL Lines with Enhanced Reconstruction (PROPELLER) MRI; Application to Motion Correction. 7th Sci Meet ISMRM, Philadelphia [Internet]. 1999;1(1991):1998.

15. Rosenkrantz AB, Mannelli L, Mossa D, Babb JS. Breath-hold T2-weighted MRI of the liver at 3 T using the BLADE technique: Impact upon image quality and lesion detection. Clin Radiol [Internet]. 2011; 66(5):426-33. https://doi.org/10.1016/j.crad.2010.10.018

16. Sandhu GS, Blackham KA, Sunshine JL. Comparison of Brain MR Images at 1 . 5T Using BLADE and Rectilinear Techniques for Patients. Ajnr. 2012; 33(1):77-82. https://doi.org/10.3174/ajnr.A2737

17. Tamhane AA, Arfanakis K. Motion correction in periodically-rotated overlapping parallel lines with enhanced reconstruction (PROPELLER) and turboprop MRI. Magn Reson Med. 2009; 62(1):174-82. https://doi.org/10.1002/mrm.22004

18. Zhang L, Tian CM, Wang PY, Chen L, Mao XJ, Wang SS, et al. Comparative study of image quality between axial T2-weighted BLADE and turbo spin-echo MRI of the upper abdomen on 3.0 T. Jpn J Radiol. 2015; 33(9):585-90. https://doi.org/10.1007/s11604-015-0463-9

How to cite this article: Safiye Sanem Dereli Bulut, Fuad Nurili, Hadi Sasani, Omer Aras, Yasar Bukte. Diagnostic Performance of T2- weighted sequences in Upper Abdominal Magnetic Resonance Imaging: BLADE Technique or HASTE Technique? J Clin Med Kaz. 2019; 1(51):37-43 